\title{
Galician Language
}

National Cancer Institute

\section{Source}

National Cancer Institute. Galician Language. NCI Thesaurus. Code C153932.

An Indo-European language of the Western Ibero-Romance branch spoken in the Galicia community of northwestern Spain. 